\title{
Pharmacognostic Evaluation \& Antimicrobial Activity of Endangered Ethnomedicinal Plant Crepidium acuminatum (D. Don) Szlach
}

\author{
Mamta Arora' ${ }^{1}$, Gurjinder Kaur ${ }^{2}$, Parvinderdeep S Kahlon ${ }^{3}$, Anupama Mahajan ${ }^{4}$, Jaspreet K Sembi ${ }^{5}$
}

\section{Mamta Arora', Gurjinder Kaur², Parvinderdeep S Kahlon ${ }^{3}$, Anupama Mahajan ${ }^{4}$, Jaspreet K Sembi ${ }^{5 *}$}

\section{'Department of Biotechnology,} A.S.B.A.S.J.S.M. College, Bela Rupnagar, Punajb, INDIA, Research scholar of IK Gujral Punjab Technical University, Kapurthala, Punjab, INDIA.

${ }^{2}$ St. Lawrence College (CANADA). ${ }^{3}$ Institute of Cellular and Molecular Botany, University of Bonn, Bonn, GERMANY.

${ }^{4}$ Department of Biotechnology, SUS College of Engineering and Technology, Tangori, Mohali, Punjab, INDIA.

${ }^{5}$ Department of Botany, Panjab University, Chandigarh, INDIA.

\section{Correspondence}

\section{Mamta Arora}

Associate professor, Biotechnology ASBASJSM College, Bela Rupnagarar, Punjab, INDIA.

Phone numbers:+91 9463027367 Facsimile numbers:01881-263533

E-mail: mamtaarora.2007@rediffmail. com

History

- Submission Date: 20-05-2017;

- Review completed: 21-07-2017

- Accepted Date: 02-11-2017

\section{DOI : 10.5530/pj.2017.6s.158}

Article Available online

http://www.phcogj.com/v9/i6s

Copyright

(C) 2017 Phcog.Net. This is an openaccess article distributed under the terms of the Creative Commons Attribution 4.0 International license.

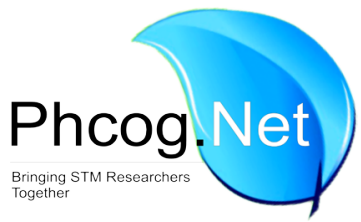

\begin{abstract}
Background: Crepidium acuminatum (D. Don) Szlach (family Orchidaceae) is an ethnomedicinal plant. It is used in breathing disorders, burning sensation, Cough, decrease in bone tissue, blood disorders, tuberculosis, as refrigerant, aphrodisiac, in insect bites, rheumatism, as tonic and in general debility. It is vital component of Ayurvedic formulation "Astavarga" with trade name "Jeevak means vitality of life. Despite the common utilization of this plant, no conclusive study has been reported so far regarding the pharmacognostic evaluation and antimicrobial activity. Aim: The present study was carried to evaluate pharmacognostic evaluation and the potential of C. acuminatum as antimicrobial. Materials and Methods: Organoleptic, histochemical, microscopic, physicochemical, extractive yield were studied to standardise pharmacognostic characters and well diffusion method were carried out for antimicrobial activity. Five extracts viz. Hexane, Chloroform, Ethanol, Ethyl acetate and aqueous were evaluated against 4 bacterial strains viz. E. coli (MTCC 40), S. aureus (MTCC 87), P. aeruginosa (MTCC 424), B. subtilis (MTCC 121). Results: The diagnostic characters were evaluated and documented. All the extracts showed good antimicrobial activity. Conclusion: Obtained standards will provide referential information for correct identification, purity, standardization and preparation of monograph. The work confirms that the studied plant has potent antimicrobial activity and has potential for antimicrobial drug. These results may constitute a basis for promising future applied research that could investigate the use of this plant as antimicrobial drug. Key words: Crepidium acuminatum (D. Don) Szlach, Pharmacognostic Evaluation, Physicochemical, Histochemical, Zone of Inhibition, Antimicrobial.
\end{abstract}

\section{INTRODUCTION}

Natural products are utilized as therapeutics. ${ }^{1} \mathrm{~A}$ large percentage of the world's population depends upon natural products for medicine. Folk medicine and ecological awareness suggest that natural products are harmless. ${ }^{2}$ therefore trend is shifting from synthetic to herbal medicine, which has been called as 'Return to Nature..3 India, have a pluralistic healthcare system. Herbal drugs constitute a major share of all the formally recognised systems of health in India viz. Ayurveda, Yoga, Unani, Siddha, Homeopathy and Naturopathy, except Allopathy. Almost, 70\% modern medicines in India are derived from natural products. ${ }^{4}$ Natural products sustained to play a highly substantial role in the drug discovery and development process. ${ }^{5}$ Medicinal plants play a crucial role not only as traditional medicines but also as trade commodities. ${ }^{6}$ The role of information derived ethno medicine and its utility for drug discovery purposes is important. ${ }^{7}$ A lot of work has been done on ethnomedicinal plants in India but still some important plants are still to be scrutinized. Plants are rich in a wide variety of secondary metabolites such as tannins, terpenoids, alkaloids, flavonoids, glyco- sides, etc., which have been found in vitro to have pharmacological properties. ${ }^{8}$

Crepidium acuminatum (D.Don) Szlach belonging to family Orchideaceae has been selected for the present study. It is an ethnomedicinal plant which is one of the eight drugs that comes under Astavarga. ${ }^{9}$ In Indian system of medicine, its medicinal value is due to pseudobulbs and traded with name Jeevak. ${ }^{10}$ This species grows in colonies in shady places, moist ground and in wet and mossy area. One colony contains 5-25 individuals, form mycorrhizal relation with a special fungus. The fungus attacks on the outer layer root cells which provide the nutrients to the plants that is essential for seed germination. ${ }^{11,12}$ This species turned to be endangered due to several reasons like loss of forest due to animal grazing, anthropogenic activity and large collection of the rhizomes for drug preparation. ${ }^{13}$

Extensive literature survey has been done on this plant. This plant has been reported by other vernacular names as Malaxis acuminata D.Don, Microstylis walichii Lindl. ${ }^{14}$ In Ayurveda Crepidium

Cite this article: Arora M, Kaur G, Kahlon PS, Mahajan A, Sembi JK. Pharmacognostic Evaluation \& Antimicrobial Activity of Endangered Ethnomedicinal Plant Crepidium acuminatum (D. Don) szlach. Pharmacog J. 2017;9(6)Suppl:s56-s63. 
acuminatum (D.Don) Szlach has been stated in many Ayurvedic formulation such as Astavarga churna, chyavanprash Rasayan, Ghrita, Taila, Gutika, Agada etc. ${ }^{14,15}$ As it is a ethnomedicinal plant, it used in Svasa (breathing disorders ,dyspnea), Daha (burning sensation), Kasa (Cough), Ksaya(decrease in bone tissue), Raktapitta(bleeding disorder), Raktavikara(blood disorders), Sosa(tuberculosis). It is reported to be refrigerant therefore used to reduce fever (Febrifuge). It has been described as aphrodisiac and used in emaciation, seminal weakness. It is also used in insect bites and rheumatism. It is used as tonic and in general debility. ${ }^{11-18}$ It has been found that in spite of its ethnomedicinal value, little work has been done on this plant.

In the current investigation carried out, pharmacognostic evaluation and screening of different extracts of C. acuminatum pseudobulbs have been used against various types of bacteria in order to screen new sources of antimicrobial agents.

\section{MATERIALS AND METHODS}

\section{Collection and Authentication of Plant Material}

The pseudo bulbs of the plant C. acuminatum (family Orchidaceae) were purchased from Chandigarh in the month of February 2014 were air dried, powdered and stored in air tight container. Pseudo bulbs were authenticated and identified as Crepidium acuminatum (D.Don) Szlach from National Institute of Science Communication and Information Resources (NISCAIR), New Delhi. Pharmacognostic evaluation was done as per WHO Guidelines. ${ }^{19}$

\section{Chemicals}

All reagents and chemicals used for pharmacognostic evaluation and antimicrobial activity were of analytical grade.

\section{Pharmacognostic Evalaution}

The organoleptic studies were carried out by with sense organs using simple technique like shape, size, colour, odour, taste etc. Histochemical reactions were applied with concentrated hydrochloric acid and phloroglucinol for identification of lignified elements, iodine solution for starch grains, Sudan red-III for cuticle layer and oil globules, Ruthenium red for mucilage and acetic acid for calcium oxalate crystals.

Microsocopic study was done by taking transverse free hand sections of the fresh pseudobulbs. Physicochemical parameters such as loss on drying, ash values, $\mathrm{pH}$ value in $1 \%$ and $10 \%$ solution, aqueous, and alcoholic extractive values were carried out according to the methods recommended by the World Health Organization. ${ }^{19}$

\section{Preparation of Plant Extract}

After collection of pseudobulb samples, they were powdered. Powder material were passed through sieve no. 40 and used for extraction. Weighed powder was extracted using hexane, chloroform, ethyl acetate, ethanol and aqueous solution in Soxhlet apparatus till exhausted. The extract was evaporated at $40^{\circ} \mathrm{C}$ in rotary vacuum evaporator to dryness. $^{20}$ The extracts obtained from successive extraction i.e. Hexane extract (HE), Chloroform extract (CE), Ethyl acetate extract (EAE), Ethanol extract (EE) and residual Aqueous extract (AAE) were subjected to preliminary phytochemical screening for the detection of various phytoconstituents such as alkaloids, steroids, flavonoids, glycosides, tannins, phenolic compound, carbohydrates, proteins, amino acids and fats. ${ }^{20,21}$

\section{Test Micro-organisms and growth Media}

The antibacterial activity of different extracts were studied against four bacterial strains, two Gram-positive (Staphylococcus aureus MTCC 87, Bacillus subtilis MTCC 121) and two Gram-negative (Escherichia coli
MTCC 40, Pseudomonas aeruginosa MTCC 424) based on their pharmacological importance. All the strains of micro-organism were obtained from Microbial Type Culture Collection (MTCC), Institute of Microbial Technology, Chandigarh.

The strains of Staphylococcus aureus, Escherichia coli and Bacillus subtilis and Pseudomonas aeruginosa were maintained on nutrient broth at $37^{\circ} \mathrm{C}$ and suspension were stored in refrigerator till used.

Commercially available Mueller-Hinton agar (MHA) (Hi-media, Mumbai) was prepared according to the instructions on the leaflet. Immediately after autoclaving the media, it was allowed to cool. Freshly prepared and cooled medium was poured into glass flat-bottomed petri-plates on a level, flat surface to give a uniform depth of approximately $4 \mathrm{~mm}$. This corresponded to $30 \mathrm{ml}$ for each plate with a diameter of $90 \mathrm{~mm}$. The agar medium was allowed to cool at room temperature and unless the plates were used the same day otherwise these were stored in a refrigerator $\left(2\right.$ to $8^{\circ} \mathrm{C}$ ) for further use within seven days. Representative samples of each batch of plates were examined for sterility by incubating at $37^{\circ} \mathrm{C}$ for 24 hours or longer. ${ }^{22}$

\section{Agar Well Diffusion Method for Determination of Zone of Inhibition (ZOI)}

Antibacterial activity was carried out using well diffusion method. The test cultures were spread with the help of spreader on the top of the solidified media and allowed to dry. The tests were conducted with $100 \mathrm{mg} / \mathrm{ml}$ concentrations of the crude extract per well with three replicates.

Dimethyl Sulphoxide (DMSO) (Himedia Mumbai) was used as negative

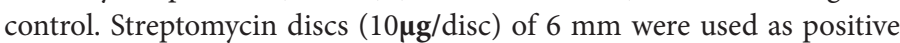
control. The plates were incubated for $24 \mathrm{~h}$ at $37^{\circ} \mathrm{C}$. Zone of inhibition (ZOI) was recorded in millimetres and the experiment was repeated thrice.

The inoculums were prepared by making a direct broth suspension of 24-hour agar plate. The suspension adjusted to match the $0.5 \mathrm{McFarland}$ turbidity standards. Dried extracts were accurately weighed and dissolved in the DMSO to yield the $100 \mathrm{mg} / \mathrm{ml}$ concentration, using sterile glassware. These were stored in refrigerator for further use. The wells were made in the incubated MHA media plates with the help of sterile cork borer (steel) of $4 \mathrm{~mm}$ and plates were labelled properly. $50 \mu \mathrm{l}$ of the working solution of plant extract were loaded into the respective wells with the help of micropipette. The plates were incubated $24 \mathrm{~h}$ at $37 \mathrm{C}$. The plates were then observed for the zone of inhibition (ZOI) produced by the anti- bacterial activity of different plant extracts. At the same time ZOI of different organism by different extracts were measured with the help of the ruler for the estimation of effectiveness of anti- bacterial substance and tabulated.

The plates were then incubated in the inverted position at $37^{\circ} \mathrm{C}$ for $24 \mathrm{~h}$ The diameters of the zones of complete inhibition as observed by the unaided eye are measured, including the diameter of the disc/well. Zones were measured to the nearest whole millimetre, using a ruler, The petri plate is held in non-reflecting background and illuminated with reflected light. The zone margin were taken area showing no obvious, visible growth which can be detected with the unaided eye. The same procedure was followed for each strain and extract. ${ }^{23}$

\section{RESULTS}

\section{Pharmacogostic evaluation}

Pharamcognostic evaluation has been done with respect to organoleptic properties, histochemical evaluation, microscopy and physicochemical studies and successive extraction yield. 


\section{Organoleptic evaluation}

Organoleptic evaluation which is done by sense organs is the simplest and quickest means to ascertain the identity and purity of a drug. Organoleptic characters as shape, size, colour, odour, taste etc. are evaluated. These features of the pseudo bulb powder of C. acuminatum sample were observed. The details of results are presented in Table1.

\section{Histochemical Characters}

Powder study by using particular chemicals has been done. The results are presented in Table 2 .

\section{Physicochemical Analysis}

The parameters which have been studied are moisture content, loss on drying, total ash, acid-insoluble ash, alcohol and water-soluble extractive values, swelling index, foreign matter, foaming index and $\mathrm{pH}$ analysis.

Ash values are useful to indicate presence of various impurities like carbonate, oxalate and silicate. The water soluble ash indicates amount of inorganic compound present in drugs whereas the acid insoluble ash indicate contamination with earthy material. Moisture content of drugs should be at minimal level to discourage the growth of microorganisms during storage. Extractive values establish the amount of the active constituents. The extractions of any crude drug with a particular solvent yield a solution containing altered phytoconstituents. The compositions of these phytochemicals depend upon the nature of the plant and the

Table 1: Organoleptic evaluation of pseudobulbs of Crepidium acuminatum D. Don Szlach

\begin{tabular}{ccc}
\hline S.No. & Parameters & Observation \\
\hline 1. & Colour & Green (fresh) and brown (dry form) \\
2. & Taste & Slightly bitter and astringent in taste \\
3. & Shape & Conical \\
4. & Odour & Characteristic \\
6. & Size & $3-9 \mathrm{~cm}$ long and 1-3 cm in diameter \\
7. & Surface & $\begin{array}{c}\text { Fleshy, smooth and shining. Covered with } \\
\text { membranous sheath }\end{array}$ \\
\hline
\end{tabular}

Table 2: Histochemical study of pseudobulb powder

\begin{tabular}{|c|c|c|c|c|}
\hline S.No. & Reagents & Test & $\begin{array}{l}\text { Nature } \\
\text { of colour } \\
\text { change }\end{array}$ & Results \\
\hline 1. & Ruthenium red & Mucilage & Pink & +ve \\
\hline 2. & Weak Iodine solution & Starch & Blue & +ve \\
\hline 3. & Sudan III & $\begin{array}{l}\text { Fixed oil and } \\
\text { fats }\end{array}$ & Pink & +ve \\
\hline 4. & Sulphuric acid (60\%) & $\begin{array}{c}\text { Calcium } \\
\text { oxalate }\end{array}$ & $\begin{array}{l}\text { Soluble, on } \\
\text { standing } \\
\text { show needles } \\
\text { of calcium } \\
\text { sulphate }\end{array}$ & $+\mathrm{ve}$ \\
\hline 5. & Phloroglucinol-HCl & Lignins & $\begin{array}{l}\text { Reddish } \\
\text { brown to red } \\
\text { rose }\end{array}$ & $+\mathrm{ve}$ \\
\hline 6. & Millon's reagent & Protein & $\begin{array}{l}\text { Yellow to } \\
\text { brown }\end{array}$ & -ve \\
\hline
\end{tabular}

(+): present; (-): absent solvent used. Results of physicochemical analysis of pseudo bulbs of C. acuminatum has been presented in Table 3 .

\section{Microscopic study}

Parenchyma tissue was irregular having large air spaces and vascular bundles were scattered throughout the ground tissue. Calcium oxalate crystals were seen which were confirmed by histochemistry. Conspicuous mucilaginous canals were present.

\section{Successive solvent extraction with hexane, chloroform, ethyl acetate, ethanol and water}

Percentage yield and physical characteristic of various extracts of C. acuminatum pseudobulb sample are shown in Table 4.

\section{ANTIMICROBIAL ACTIVITY}

Results obtained in the present study revealed that tested extracts possess potential antibacterial activity against E. coli, S. aureus, P.aeruginosa, B.subtilis. When tested by disc diffusion method the chloroform, Ethyl Acetate and Ethanol pseudobulbs extracts showed most promising results. The maximum ZOI has been observed with chloroform extract viz. $20 \mathrm{~mm}$ has been observed against E. coli, followed by B. subtilis $(15.33 \mathrm{~mm})$, S. aureus $(14.33 \mathrm{~mm})$ and least with aqueous extract. Ethyl Acetate pseudobulb extract of $C$. acuminatum exhibit highest activity against E.coli of $18.66 \mathrm{~mm}$ followed by B. subtilis $13.33 \mathrm{~mm}$, S. aureus $10.33 \mathrm{~mm}$ and least against $P$. aeruginosa $8 \mathrm{~mm}$. Ethanol extract showed maximum activity against $E$. coli $15.33 \mathrm{~mm}$ followed by $S$. aureus $12.33 \mathrm{~mm}$, B. subitilis $11 \mathrm{~mm}$ and least in $P$. aeruginosa $8 \mathrm{~mm}$. Hexane extract showed highest activity against B.subtilis as $9.33 \mathrm{~mm}$ almost same as for S.aureus $9.17 \mathrm{~mm}$. hexane extract showed equal activity against E.coli

\section{Table 3: Physicochemical parameters of $C$. acuminatum}

\begin{tabular}{ccc}
\hline S.No. & Physicochemical Parameter & $\%$ Value $(\% \mathrm{w} / \mathrm{w})$ \\
\hline 1. & Total ash value & $1.49 \%$ \\
2. & Acid-insoluble ash value & $0.49 \%$ \\
3. & Water soluble ash value & $0.99 \%$ \\
4. & LOD & $6.52 \%$ \\
5. & $\mathrm{pH} 1 \%$ Solution & 7.5 \\
6. & $\mathrm{pH}$ 10\% Solution & 6.8 \\
7. & Moisture content & $53 \%$ \\
8. & Foreign Matter & $2 \%$ \\
9. & Alcohol soluble extractive value & $4 \%$ \\
10. & Water soluble extractive value & $16.5 \%$ \\
11. & $80 \%$ ethanol soluble extractive & $0.95 \%$ \\
12. & Alcohol soluble extractive value & $4 \%$ \\
13. & Swelling Index & $12.5 \%$ \\
14. & Foaming index & Less than 100 \\
\hline
\end{tabular}

Table 4: Extractive yields of different extracts

\begin{tabular}{cccccc}
\hline Sr. No. & Extract & $\%$ Yield & Colour & Odour & Consistency \\
\hline 1. & HE & $0.95 \%$ & Dark green & Characteristic & Sticky \\
2. & CE & $0.8 \%$ & Brown & Characteristic & Sticky \\
3. & EAE & $0.57 \%$ & Dark brown & Characteristic & Sticky \\
4. & EE & $1.55 \%$ & Dark brown & Characteristic & Sticky \\
5. & AE & $5.45 \%$ & Dark brown & Characteristic & Sticky \\
\hline
\end{tabular}


Table 5: zone of inhibition (in $\mathrm{mm}$ ) of different extracts of pseudobulbs of Crepidium acuminatum (D.Don) Szlach against different microorganisms

\begin{tabular}{|c|c|c|c|c|}
\hline ORGANISMS & E. coli & S. aureus & P aeruainosa & B subtilis \\
\hline$\rightarrow$ & MTCC 40 & MTCC 87 & MTCC 424 & MTCC 121 \\
\hline EXTRACT & (gram -ve) & (gram + ve) & (gram -ve) & (gram + ve) \\
\hline \multirow[t]{2}{*}{$\downarrow$} & Zone of Inhibition & Zone of Inhibition & Zone of Inhibition & Zone of Inhibition \\
\hline & (diameter in $\mathrm{mm}$ ) & ( diameter in $\mathrm{mm}$ ) & ( diameter in $\mathrm{mm}$ ) & (diameter in $\mathrm{mm}$ ) \\
\hline Aqueous & $6.5 \pm 0.00$ & $7.0 \pm 0.00$ & $8.0 \pm 0.00$ & $6 . .5 \pm 0.22$ \\
\hline + ve Control & 19 & 7 & 24.5 & 24 \\
\hline -ve Control & 0 & 0 & 0 & 0 \\
\hline Hexane & $8.0 \pm 0.00$ & $9.17 \pm 0.17$ & $8.0 \pm 0.00$ & $9.33 \pm 0.33$ \\
\hline +ve Control & 19 & 7 & 24.5 & 24 \\
\hline -ve Control & 0 & 0 & 0 & 0 \\
\hline Chloroform & $20.0 \pm 0.00$ & $14.33 \pm 0.33$ & $10.5 \pm 0.29$ & $15.33 \pm 0.33$ \\
\hline +ve Control & 19 & 7 & 24.5 & 24 \\
\hline -ve Control & 0 & 0 & 0 & 0 \\
\hline Ethanol & $15.33 \pm 0.33$ & $12.33 \pm 0.33$ & $10.33 \pm 0.33$ & $11.0 \pm 0.58$ \\
\hline +ve Control & 19 & 7 & 24.5 & 24 \\
\hline -ve Control & 0 & 0 & 0 & 0 \\
\hline Ethyl acetate & $18.66 \pm 0.33$ & $10.33 \pm 0.33$ & $8.0 \pm 0.00$ & $13.33 \pm 0.33$ \\
\hline +ve Control & 19 & 7 & 24.5 & 24 \\
\hline -ve Control & 0 & 0 & 0 & 0 \\
\hline
\end{tabular}

and $P$. aeruginosa. Aqueous extract exhibited least activity among all the extracts tested. The data pertaining to the antimicrobial potential of the plant extracts are presented in Table 5 (results as mean \pm standard error, standard error was calculated by on line statistical tool)

It is clear from the Table 5 that antibacterial activities of different extracts are showing promising results. The growth inhibition zone measured ranged from $6.5 \mathrm{~mm}$ to $20 \mathrm{~mm}$. Trend of the activity of different extracts against E.coli and S. aureus is same i.e. Chloroform $>$ Ethyl acetate $>$ Ethanol $>$ Hexane $>$ Aqueous. Maximum ZOI has been observed for Chloroform extract i.e. $20 \mathrm{~mm}$ and least ZOI for aqueous i.e. $6.5 \mathrm{~mm}$. Antibacterial activity against $P$. aeruginosa MTCC 424 has been observed in the pattern as Chloroform $>$ Ethanol $>$ Ethyl acetate $=$ Hexane $=$ Aqueous whereas antibacterial activity against B.subtilis MTCC 121 has been observed as Chloroform $>$ Ethyl acetate $>$ Ethanol $>$ Hexane $>$ Aqueous.

It is clear from Figure $1 \mathrm{~A}$ that Chloroform extract is showing more promising anti E. coli activity as compared to standard. Similarly ZOI is more against $S$ aureus by Chloroform, Ethanol extract. Figure1B showed that $\mathrm{ZOI}$ in chloroform extracts of $C$. acuminatum is more as compared to positive control when tested against $E$. coli.

Figure 1C showed that tested extracts either exhibit equal or more activity as compared to standard when tested against $S$. aureus. Figure 1D showed that extracts are least effective against P.aeruginosa as compared to other strains tested. Figure 1E showed good activity of chloroform extract against B.subtilis as compared to other tested extracts. Figure 2 showed Zone of Inhibition against various microbes. Streptomycin was used as positive control and DMSO as negative control

\section{DISCUSSION}

Ethno pharmacologists, Botanists, Microbiologists, Biotechnologists and natural-Products Chemists are exploring the mother Earth for phytochemicals and "leads" which could be developed into medicine. Plants are rich in secondary metabolites like tannins, terpenoids, alkaloids and flavonoids and these secondary metabolites are responsible for antibacterial properties. The use of plants and its preparations to treat diseases is an ancient practice in world especially in developing countries like India where there is dependence on traditional medicine. Interest in plants with antibacterial properties has revitalized as a result of current problems associated with the use of antibiotics. The present studies aimed at the investigation of C. acuminatum Endangered ethnomedicinal orchid plant in vitro antibacterial activity against Gram positive and Gram negative bacteria. The results presented here point out that this plant is a good choice for the development of new "leads".

Hexane, chloroform, ethyl acetate, ethanol and aqueous extracts of C. acuminatum pseudobulb extracts showed significant zone of inhibition against "Gram-positive" bacteria, Staphylococcus aureus MTCC 87, Bacillus subtilis MTCC 121 and Gram-negative bacteria Pseudomonas aeruginosa MTCC424 and Escherichia coli MTCC 40.

This work shows that maximum ZOI has been observed in Chloroform extracts and least in aqueous extracts. This means active components showing better antibacterial property are more lipophilic as compared to hydrophilic. Phytochemicals such as alkaloid are generally reported in Chloroform extract. ${ }^{20}$ One sterol namely $\beta$-Sitosterol has been reported along with two sugars (glucose and rhamnose), Cetyl alcohol, Choline and diterpenes. ${ }^{14-24,25}$ whereas in another study Piperitone, Citronellal, Eugenol, Limonene, 1,8-Cineole, p-Cymene, o-Methylbatatasin, has been reported by thin layer chromatography. ${ }^{10-26}$ whereas in another study metal content and volatile constituents in Microstylis wallichii (C. acuminatum) which were analyzed by Atomic Absorption Spectrophotometer and GC and GC-MS. Not much work has been done on the phytoconstituents of this plant. Sharma, P and coworkers ${ }^{27}$ studied The antimicrobial activity of pseudobulbs of Malaxis acuminata using the Butanol extract against some gram (+)ve, Gram (-)ve bacteria and fungi by agar cup diffusion method against Escherichia coli, Klebsiella aerogenes, Pseudomonas aeruginosa, Proteus mirabilis, Staphylococcus aureus and fungus, Candida albicans. The butanol extract showed better fungal inhibition than bacterial inhibition. They observed $19 \mathrm{~mm}$ and $18 \mathrm{~mm}$ ZOI with E. coli and S. aureus respectively at $50 \mathrm{mg} / \mathrm{ml}$ concentration. 


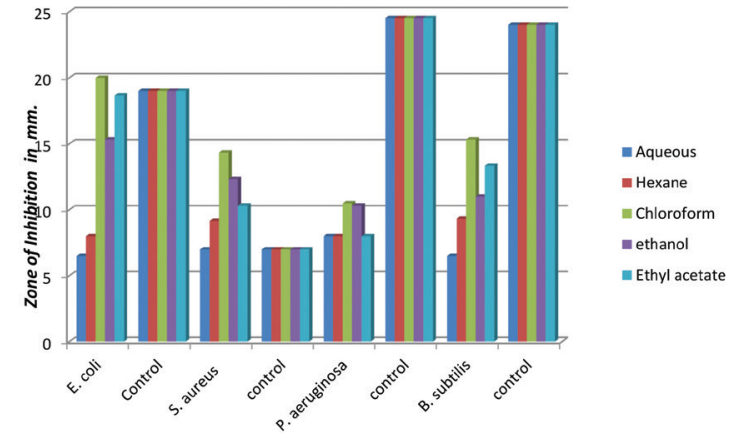

1A Showing antibacterial activity of different extracts against mentioned bacterial strains as compared to standard

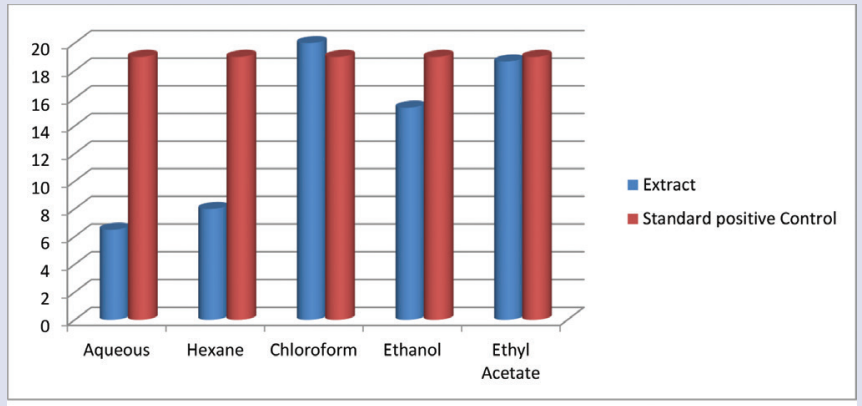

B. In vitro anti- E.coli activity of Crepidium acuminatum D.Don. Szlach extracts $100 \mathrm{mg} / \mathrm{ml}$ dissolved

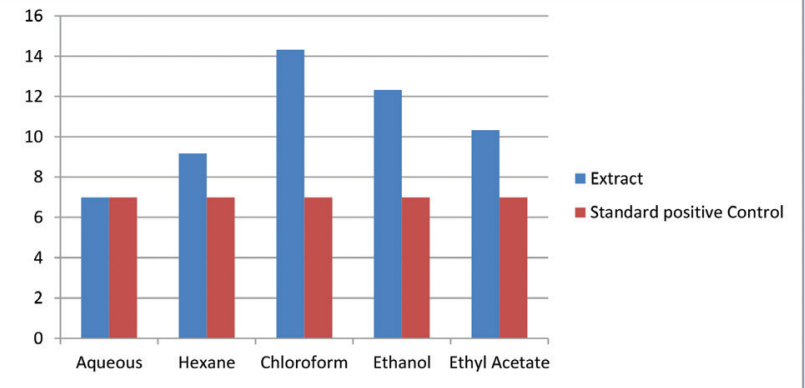

C. In vitro anti-S.aureus activity of Crepidium acuminatum D.Don. Szlach extracts 100 $\mathrm{mg} / \mathrm{ml}$ dissolved in DMSO and of antibiotic Streptomycin $10 \mathrm{ug} / \mathrm{disc}$

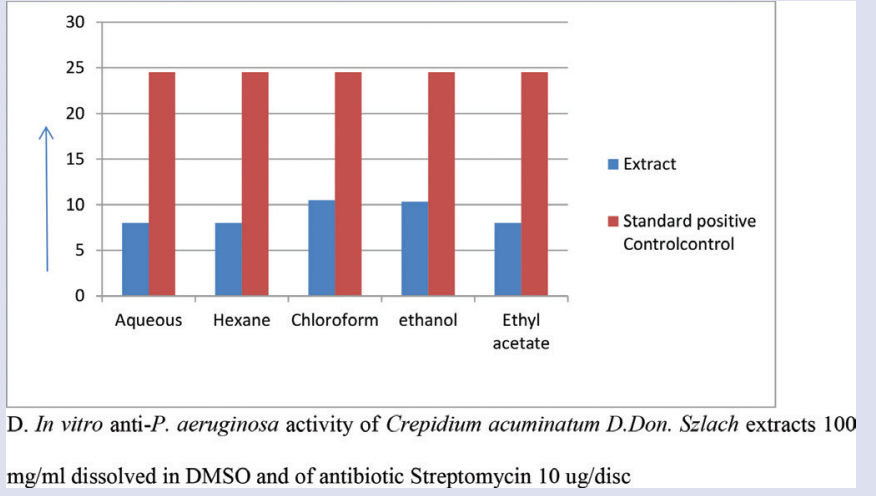

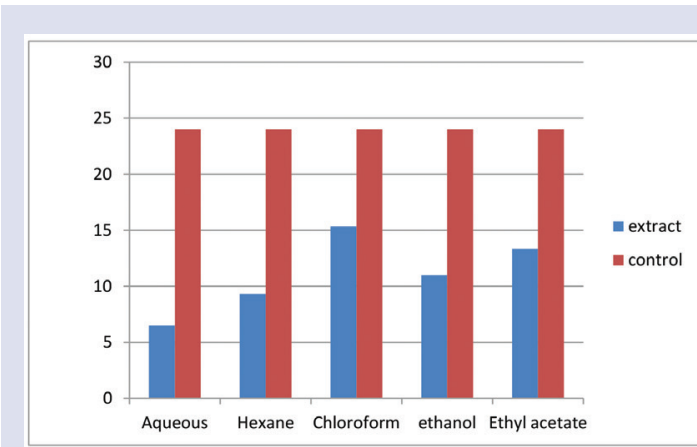

E In vitro anti-B.subtilis activity of Crepidium acuminatum D.Don. Szlach extracts 100 $\mathrm{mg} / \mathrm{ml}$ dissolved in DMSO and of antibiotic Streptomycin $10 \mathrm{ug} / \mathrm{disc}$

Figure 1: Antimicrobial activity response (ZOI) of extracts of different extracts of pseudobulbs of the plant. X-Axis -Types of extracts, Y-Axis-Zone of Inhibition in $\mathrm{mm}$. DMSO is negative control and antibiotic Streptomycin $10 \mathrm{ug} /$ disc as positive control

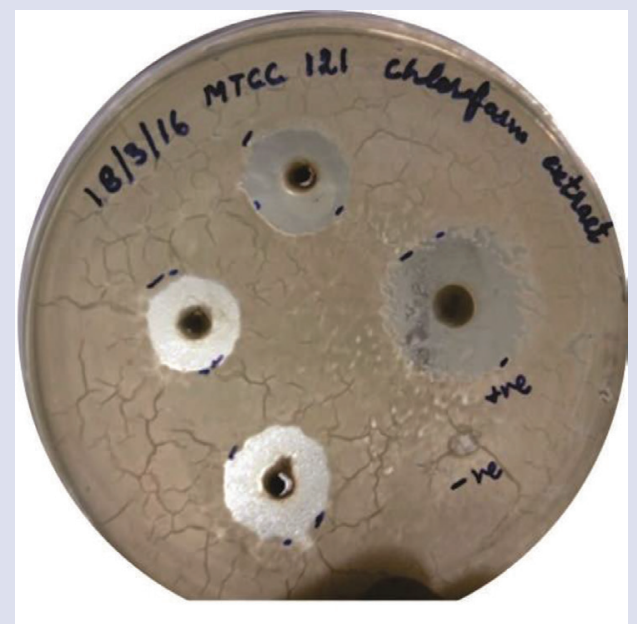

2A ZOI of Chloroform extract against MTCC121

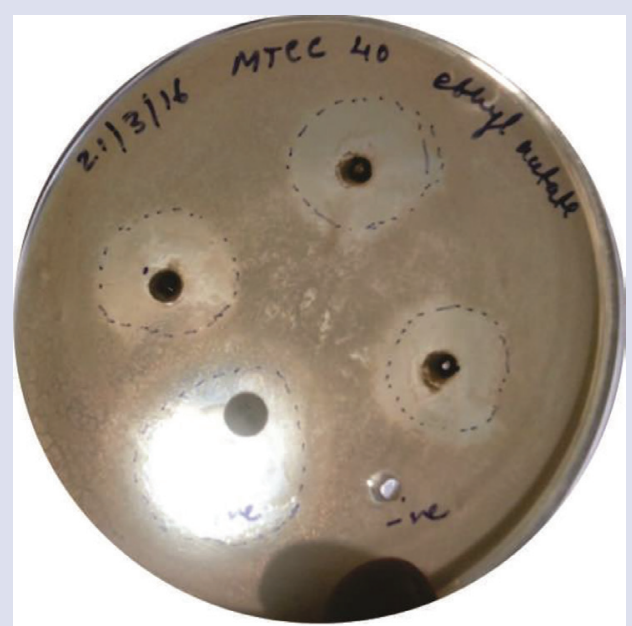

B ZOI of Ethyl acetate extract against MTCC 40 


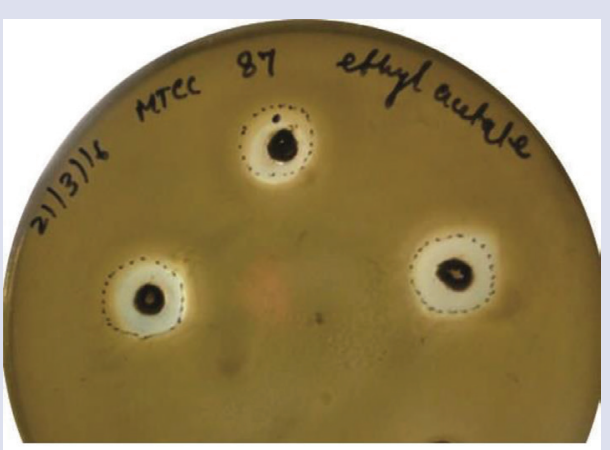

C ZOI of Ethyl acetate against MTCC 87

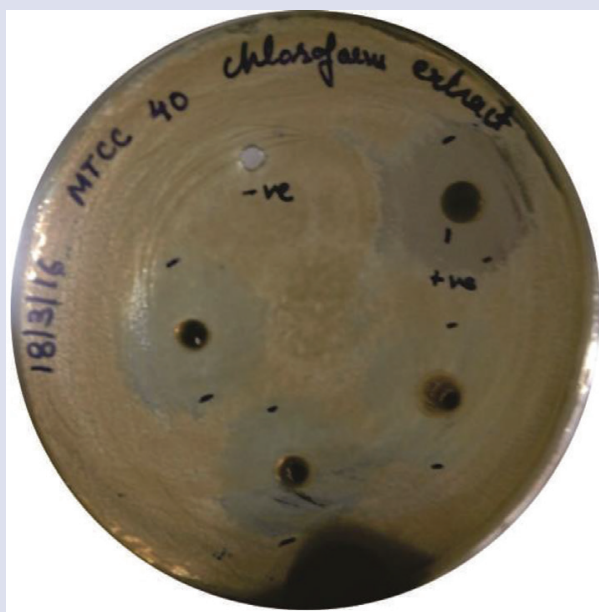

D ZOI of Hexane extract against MTCC 424

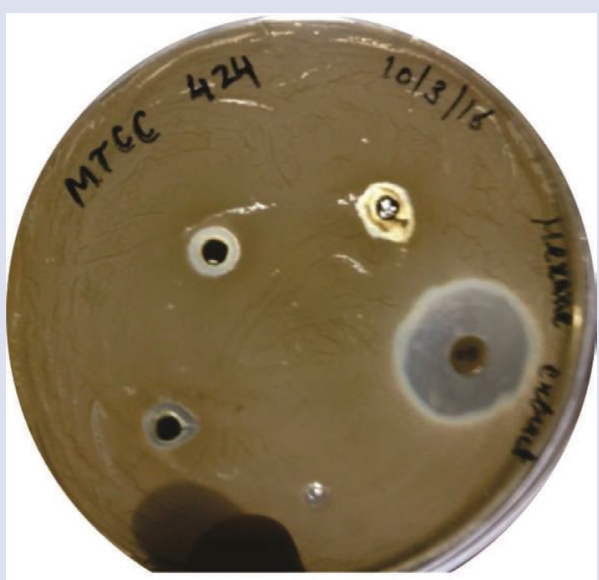

E ZOI of chloroform extract against MTCC 40

Figure 2: Antimicrobial activity of different extracts of pseudo bulbss against different microorganism Staphylococcus aureus MTCC 87, Bacillus subtilis MTCC 121 and Gram-negative bacteria Pseudomonas aeruginosa MTCC424 and Escherichia coli MTCC 40 (DMSO is negative control, antibiotic Streptomycin $10 \mathrm{ug} /$ disc is positive control)
In another study ${ }^{28}$ antimicrobial properties against pathogenic microbial strains namely Pseudomonas aeruginosa (MTCC 4676) and Staphylococcus aureus (MTCC 7405) have been reported. The maximum activity out of the tested plants by them C. acuminatum was most active and out of various extracts studied by them ethanolic and methanolic extracts of the plant was found to be highly active against the test bacteria. The antioxidant activity of Malaxis acuminata was studied by Sharma, P. ${ }^{29}$ by using methods:1, 1-diphenyl-2-picryl hydrazyl(DPPH) radical scavenging activity, Reduction capability by Fe3+-Fe2+ Transformation method and Hydrogen peroxide scavenging method. The results predicted that the extract showed a good antioxidant activity. Ethanolic $(50 \% \mathrm{v} / \mathrm{v})$ extracts of Carissa carandas (fruits) (Apocynaceae) and Microstylis wallichii (tubers) (Orchidaceae) were considered ${ }^{30}$ for anti-inflammatory and analgesic activities in experimental animals. Extracts of both plants $(50-200 \mathrm{mg} / \mathrm{kg}$ ) caused a dose dependent inhibition of swelling caused by carrageenin significantly in cotton pellet induced granuloma in rats. A significant increase occurred in the analgesic meter induced pain in rats.

The studies commenced here also suggest that presence of good antibacterial potency of the extracts is due to active compounds in the extracts. The results indicate that the tested crude extracts are potential source to be explored to identify new compounds.

As this plant is used in Ayurvedic formulations the results also revealed the scientific basis of the traditional usage of $C$. acuminatum and therefore received attention.

This is supporting document to prove that this plant has therapeutic uses since ancient times. The use and exploration for drugs and dietary supplements derived from this plant have accelerated recently but much work has to be done.

\section{CONCLUSION}

Pharmacognostic evaluation play an important role in quality control of the crude drug. The different characters observed in the pseudobulbs of $C$. acuminatum serve as base for the identification of right sample of the plant as drug and other studies. Five extracts have been selected out of which Chloroform extract, Ethyl Acetate and ethanol extracts have shown more promising results as compared to hexane and Aqueous extracts. It can be concluded from this study that chloroform, ethyl acetate and ethanol are more suitable for further studies. Antibacterial leads seem to be more lipophilic in nature. The ZOI in chloroform extract is found to be even more as compared with standard drug Steptomycin against E. coli MTCC 40. The present study justified the claimed uses of pseudobulbs in the traditional system of medicine to treat various infectious disease caused by the microbes. However, further studies are needed to better evaluate the prospective efficacy of the crude extracts as the antimicrobial agents. The present results will form the basis for selection of plant species for further investigation for the potential discovery of new natural bioactive compounds.

\section{ACKNOWLEDGEMENT}

The authors are thankful to SUSCET Tangori, Punjab and ASBASJSM College, Bela Rup agar Punjab for providing all the research facilities \&I. K. Gujral Punjab Technical University, Kapurthala, Punjab, India for invaluable support. The authors are also thankful to Dr. Satnam Singh, Department of Pharmacognosy, ASBASJSM College of Pharmacy, Bela Rupnagar for helping in research work.

\section{CONFLICTING INTEREST}

We declare no conflict of interest 


\section{ABBREVIATIONS USED}

ZOI: Zone of Inhibition; MTCC: Microbial type culture collection centre; DMSO: Dimethyl sulphoxide.

\section{REFERENCES}

1. Cragg GM, Newman DJ. Biodiversity: A continuing source of novel drug leads. Pure Appl Chem. 2005;77(1):7-24. doi:10.1351/pac200577010007. PMID:23428572

2. PMCID:PMC3672862

3. Rates SMK. Plants as source of drugs. Toxicon. 2001;39(5):603-13. doi:10.1016/ S0041-0101(00)00154-9

4. Sharma A, Shanker C, Tyagi LK, Singh M, Rao C V. Herbal Medicine for Market Potential in India: An Overview. Acad J Plant Sci. 2008;1(2):26-36. doi:10.1177/1534582306289130

5. Vaidya ADB, Devasagayam TPA. Current Status of Herbal Drugs in India: An Overview. J Clin Biochem Nutr. 2007;41(1):1-11. doi:10.3164/jcbn.2007001.

6. Newman DJ, Cragg GM, Newman DJ, Cragg GM. Natural Products as Sources of New Drugs over the Last 25 Years Natural Products as Sources of New Drugs over the Last 25 Years $\perp$. 2007;70:477. doi:10.1021/np068054v.

7. http://health.economictimes.indiatimes.com/news/pharma/indiasshare-in-global-herbal-medicinal-market-is-0-5-pcgovt/55505280 (Accessed on 24 November, 2016)

8. Fabricant DS, Farnsworth NR. The value of plants used in traditional medicine for drug discovery. Environ Health Perspect. 2001:109(SUPPL. 1):69-75. doi:10.1289/ehp.01109s169.

9. Cowan MM. Plant products as antimicrobial agents. Clin Microbiol Rev. 1999;12(4):564-582. doi:0893-8512/99/\$04.00+0

10. Pérez Gutiérrez RM. Orchids: A review of uses in traditional medicine, its phytochemistry and pharmacology. J Med Plants Res. 2010;Vol.4(8), (18 April):592-638. doi:10.5897/JMPR10.012

11. Lohani N, Tewari LM, Joshi GC, et al. Chemical composition of Microstylis wallichii Lindl. from Western Himalaya. J Med Plants Res. 2013;7(31):2289-92. doi:10.5897/JMPR11.1754.

12. Sharma P, Mahajan N, Garg P, Singh G, Sumit D, Sharma S. Malaxis Acuminata : a Review. Int J Res Ayurveda Pharm. 2011;2(2):422-25.

13. Cheruvathur MK., Abraham J, Mani B, Thomas TD. Adventitious shoot induction from cultured intermodal explants of Malaxis acuminata D.Don, avaluable terrestrial medicinal orchid.Plant Cell Tiss Org 2010;101:163-70 doi:10.1007/ s11240-010-9673-0

14. Arenmongla T, Deb CR. Germination of immature embryos and multiplication of Malaxis acuminata D. Don, an endangered therapeutically important orchid, by asymbiotic culture in vitro. Indian J Biotechnol. 2012;11(4):464-9.

15. Teoh ES. Medicinal Orchids Of Asia. Springer International Publishing 2016:(1):212-./3 doi/10.1007/978-3-319-24274-3
16. Anonymous. The Ayurvedic Pharmacopoeia of India, Part 1, Vol. 5, 78-80 1st Ed., New Delhi, Ministry of Health and Family Welfare, Department of AYUSH, Govt. of India, 2008. Available from http://www.ayurveda.hu/api/API-Vol-5.pdf

17. Nambiar VPK. Indian Medicinal Plants: A Compendium of 500 species $1993 ; 3$ Available from https://books.google.co.in/books?id=mBB_aRjQlo0C\&source= gbs_book_other_versions

18. Pant B. Medicinal orchids and their uses: Tissue culture a potential alternative for conservation. African Journal of Plant Science 2013;7: 448-67. https://doi. org/10.5897/AJPS2013.1031

19. Hossain MM. Traditional therapeutic uses of some indigenous orchids of Bangladesh. Med Arom Plant Sci Biotechnol. 2009;42(1):101-6.

20. WHO guidelines. Quality control methods for medicinal plant materials. WHO Geneva 1998:8-78.

21. Khandelwal KR. Practical Pharmacognosy Techniques and Experiments. Nirali prakashan : pune. ed 92003.

22. Harborne JB. (1998). Phytochemical Methods. A guide to modern techniques of plant analysis, Chapman and Hall, London. ed. 3:1-254.

23. Narayana K., Kumar S, Saraswathy A, Amerjothy S. Antimicrobial Potential of Helicanthus elastica ( Desr .) Danser A less explored Indian mistletoe Growing on Mango Trees. Journal of Traditional and Complementary Medicine 2014; 4(4):258-62. https://doi.org/10.4103/2225-4110.126183

24. Bhalodia NR, Nariya PB, Shukla VJ. Antibacterial and antifungal activity from flower extracts of Cassia fistula L.: An ethnomedicinal plant. Int J PharmTech Res. 2011;3(1):160-68. doi:10.1016/j.jep.2007.04.008.

25. Bhatnagar JK, Handa SS, Duggal SC. Chemical investigation on Microstylis wallichii. Planta Medica 1970;20:157-61.

26. Sharma A, Rao CV, Tiwari RK, Tyagi LK, Kori, ML, Shankar K. Comparative study on physiochemical variation of Microstylis wallichii: A drug used in ayurveda. Academic journal of plant sciences 2009;2:04-08.

27. Gupta R, Aggarwal M, Baslas RK Chromatographic separation and identification of various constituents of essential oil from bulb of Malaxis acuminate. Indian Perfume 1978;22:287-8 http://www.gbv.de/dms/tib-ub-hannover/017304504.pdf

28. Sharma P, Garg P, Dadhwal S, Singh G, Sharma DK, Sharma S. Antimicrobial activity of Butanol extract of Malaxis acuminata. 2011;4(8):2703-4

29. Bharal A, Kashyap M, Sohpal V, Sembi J. Evaluation of Antimicrobial Properties of Terrestrial Orchids (Collected From Northern Himalayas) Against Certain Human. Int $J$ of Bioassays 2014;3(06):3036-9. https://ijbio.com/index.php/ijb/ article/view/453.

30. Sharma P. Antioxidant Activity of the Butanol extract of Malaxis acuminata (Jeevak). 2012;5(5):2888-9.

31. Sharma A, Reddy GD, Kaushik A, Shanker K, Tiwari RK., Mukherjee A et al Analgesic and anti-inflammatory activity of Carissa carandas Linn. Fruits and Microstylis wallichii Lindl tubers. Natural Products sciences 2007;13:6-10. http://agris.fao.org/aos/records/KR2007003141

\section{GRAPHICAL ABSTRACT}
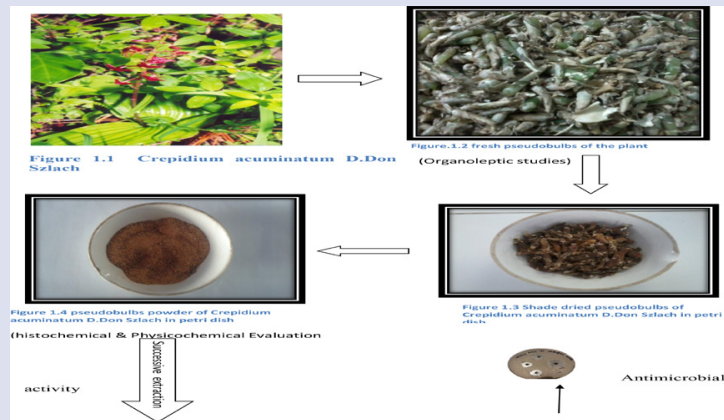

\section{SUMMARY}

- Crepidium acuminatum ( syn. Malaxis acuminata) commonly known as Jeevak is used in breathing disorders, burning sensation, Cough, decrease in bone tissue, blood disorders, tuberculosis, as refrigerant, aphrodisiac, in insect bites, rheumatism, as tonic and in general debility. It is vital component of Ayurvedic formulation "Astavarga".

- Pharmacognostic evaluation of Crepidium acuminatum has been done w.r.t. parameters organoleptic properties, histochemical evaluation, microscopy and physicochemical studies and successive extraction yield

- The studies commenced here also suggest that presence of good antibacterial potency of the extracts is due to active compounds in the extracts. The results indicate that the tested crude extracts are potential source to be explored to identify new compounds.

- The present study justified the claimed uses of pseudobulbs in the traditional system of medicine to treat various infectious disease caused by the microbes. 


\section{ABOUT AUTHORS}

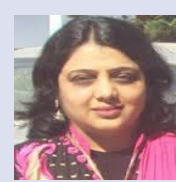

Mamta Arora: Is working as HOD Biotechnology \& Food Processing at ASBASJSM College, Bela Rupnagar (Punjab). Author has qualified NET CSIR-JRF Life Sciences in 2001 and qualified UGC-NET in Education 2006. Author has published two books. One on Human rights education and other on primary school health Care system. She has got Bharat Jyoti Award in 2016, State award by Bharat scouts and Guide Punjab 2016, State award by Punjab Kala Manch sri Chamkaur Sahib 2016, Best citizen of India award 2016 by International Publishing House, Excellence services 2008 Award, Bestowal of Excellence Award, Best Coordinator award 2012, Best Teacher Award' 2013 .Panjab Sangeeet Natak academy, Panjab Kala Parishad, Panjab Kala Bhawan Chandigarh honoured for Conducting Stage. She has presented various International and national papers. She is Convener of Internal quality assurance Cell etc.

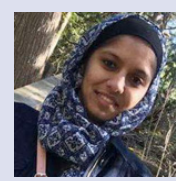

Gurjinder Kaur: Did Masters in Biotechnology. Health care administration postgraduate course from St. Lawrence College (Canada) and then International business management course from Canada and working as supervisor.

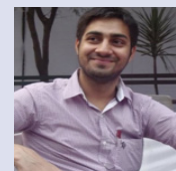

Parvinderdeep S. Kahlon: Recently completed his masters from The University of Bonn, Germany where he studied molecular, Physiological and Taxonomical aspects of Plants. He did Masters thesis on Plant Pathology at the University of Oxford, where he worked on Rcr3/Pip1 hybrids and oxidative burst assays.

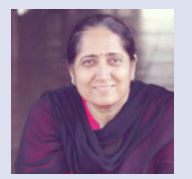

Dr. Anupama Mahajan: Is working as Assistant Professor in Biotechnology at SUSCET Tangori. Author has done Ph.D. from panjab University.

Dr. Jaspreet K. Sembi: Is leading a research team which is involved in elucidating the molecular intricacies of flowering and other developmental pathways in orchids.

Cite this article: Arora M, Kaur G, Kahlon PS, Mahajan A, Sembi JK. Pharmacognostic Evaluation \& Antimicrobial Activity of Endangered Ethnomedicinal Plant Crepidium acuminatum (D. Don) szlach. Pharmacog J. 2017;9(6)Suppl:s56-s63. 